\title{
SOIL WATER RETENTION OF THE ODRA RIVER ALLUVIAL SOILS (POLAND): ESTIMATING PARAMETERS BY RETC MODEL AND LABORATORY MEASUREMENTS
}

\author{
BOREK, Ł.*-BOGDAE, A. \\ Department of Land Reclamation and Environmental Development, University of Agriculture in \\ Krakow, Al. Mickiewicza 24-28, 20-059 Krakow, Poland \\ (e-mail: rmbogdal@cyf-kr.edu.pl) \\ *Corresponding author \\ e-mail: l.borek@ur.krakow.pl; phone: +48-12-662-4058 \\ (Received 29 $9^{\text {th }}$ Mar 2018; accepted $12^{\text {th }}$ Jun 2018)
}

\begin{abstract}
The paper presents water retention of alluvial soils in the Odra valley. Floodplain soils are one of the most fertile intrazonal soils in Europe. The relevant field studies and laboratory tests were carried out during the vegetation seasons (2012 and 2013) on arable lands located in Tworków (south of the Silesian Province, Poland). A three pedotransfer functions (PTFs) parameter van Genuchten type model was used to describe the water retention curves of alluvial soils. Fitted soil water retention curve (SWRC) parameters were regressed linearly with a different number of soil physical properties in the RETC and Rosetta. The first model (PTF-1) uses soil textural classes, consisting of a lookup table that provides parameter averages for each USDA textural class. The second model (PTF-2) uses sand, silt, and clay percentages as input, and the third model (PTF-3) includes bulk density as a predictor. The simulation results were considered for each layer separately and as a whole for all soil profiles. The predicted values of water content of the RETC and Rosetta for each soil layer are close to the measured values $\left(\mathrm{R}^{2}=\right.$ 0.825-0.995). Simulated values of water content (all soil profiles) by PTF-3 are very similar to the measured values. The predicted values of the residual soil water content $(\theta \mathrm{r})$ and the saturated soil water content $(\theta \mathrm{s})$ by PTF-3 provided good simulation results $\mathrm{R}^{2}=0.860$ and $\mathrm{R}^{2}=0.667$, respectively. The specific alluvial soil conditions affect the high water content in the soil, which is reflected in the content of water available for plants. This information should contribute to the rational management of water resources in the agricultural area, what can be used to mitigate the effects of drought.
\end{abstract}

Keywords: water properties of soil, floodplain soil, RETC program, Poland

\section{Introduction}

Soil is a non-renewable natural resource that is essential to life. Water movement, water quality, land use, and vegetation productivity all have relationships with soil (Schoonover and Crim, 2015). Diversity of alluvial soil types has been the subject of much less study than typical mineral soils. Thus, studies focused on physical and hydraulic parameters of alluvial soils are essential for a better understanding of how alluvial ecosystems function (Luptáčik et al., 2012).

Alluvial soils have the highest productivity with respect to other soils (Huong et al., 2013). They are present mostly along rivers and are carried by its streams during weathering of rocks. Most vegetable production is on alluvial soil generally succeed. The key role in creating alluvial soil is a high ground water level (Dobrovol'ski et al., 2011; Pirastru and Niedda, 2013; Liu et al., 2015; Dwevedi et al., 2017; Yassoglou et al., 2017).

River alluvial soils are formed from silts deposited chiefly by flood-waters, from here are often called floodplain soils. Soil formation is in this case very long, in consequence, alluvial soils have, as a rule, an undeveloped profile. The natural soils in 
river-valley bottoms are almost wholly used for meadows, pastures and tilled fields (Szafer, 1966). According to Bednarek and Prusinkiewicz (1999) alluvial soils constitute about $5 \%$ of Poland's area.

As a result of soil cultivation, farmers can change some of its physical and hydraulic parameters, such as: soil compaction, soil water permeability, relations between water and air (Cameira et al., 2003; Pagliai et al., 2004; Hakl et al., 2007; Nawaz et al., 2013; Bogdał et al., 2014; Kahlon and Khurana, 2017). Soil compaction is a significant problem of agriculture nowadays. It is directly connected with the mechanization of field treatments. Compaction is a physical form of soil degradation: it changes the soil structure, water and air permeability, porosity, and it inhibits penetration by plant roots (Hakl et al., 2007; Nawaz et al., 2013).

Knowledge of the soil hydraulic properties is indispensable to solve many soil and water management problems related to agriculture, ecology, and environmental issues. The most important hydraulic properties of soils are the soil water retention curve (SWRC) and soil water permeability (Shwetha and Varija, 2015; Qanza et al., 2015). Soil hydraulic properties depend mainly on soil texture, organic matter content and bulk density (Hillel, 1998). In scientific research, many methods and types of models are used to determine the hydraulic parameters of soils (Minasny et al., 2004; Šimůnek et al., 2005; Pandey et al., 2006; Nasta et al., 2013). The role of water retention in soil has been analyzed and reviewed in many scientific studies (Van Genuchten et al., 1991; Minasny et al., 2003; Merdun et al., 2006; Wassar et al., 2016; Nguyen et al., 2017).

Modeling water flow in soil requires knowledge of soil hydraulic properties, which are water retention curves. As an alternative to direct measurement, indirect determination of these functions from basic soil properties using pedotransfer functions (PTFs) has attracted the attention of researchers in a variety of fields such as soil scientists, hydrologists, and agricultural and environmental engineers (Merdun et al., 2006; Fashi et al., 2016).

Water retention characteristics are fundamental input parameters in any modeling study on water flow and solute transport. These properties are difficult to measure and for that reason, we usually need to use direct and indirect methods to determine them. An extensive comparison between measured and estimated results is needed to determine their applicability for a range of different soils (Wassar et al., 2016).

The RETC can be useful for estimating the hydraulic parameters from retention data only with laboratory, or simultaneously from observed retention and hydraulic conductivity data and other physical parameters (Van Genuchten et al., 1991).

The objective of this study is to evaluate the water retention of the alluvial soil and the estimation of van Genuchten parameters by the three intelligent pedotransfer models RETC.

\section{Materials and methods}

\section{Study area}

The study area lies on alluvial soils located in the catchment of the Odra River on arable land in Tworków, in the south of Poland (the Racibórz District, the Silesian Province) (Fig. 1).

The average altitude of the object is $190.00 \mathrm{~m}$ a.s.l. According to the geographical division by Kondracki (2011), the object is situated in the Central European Lowlands province (31), in the macroregion of the Silesian Lowlands (318.5) and in the 
mesoregion of the Raciborska Basin (318.59), in terms of climate is considered as one of the warmest areas in this region. In general, Poland has mostly temperate climate, in transition between oceanic climate dominating in the north and west of the country, and continental climate in the south and east (Kundzewicz et al., 2017). In the multiannual period 1971-2000, average annual air temperature was $8.5{ }^{\circ} \mathrm{C}$ and total precipitation was $616 \mathrm{~mm}$ (according to the IMGW - Institute of Meteorology and Water Management - station in Racibórz). Depending on changes in meteorological conditions, there are periodically too high moisture contents in soil. The characteristics of meteorological conditions are shown in Table 1.

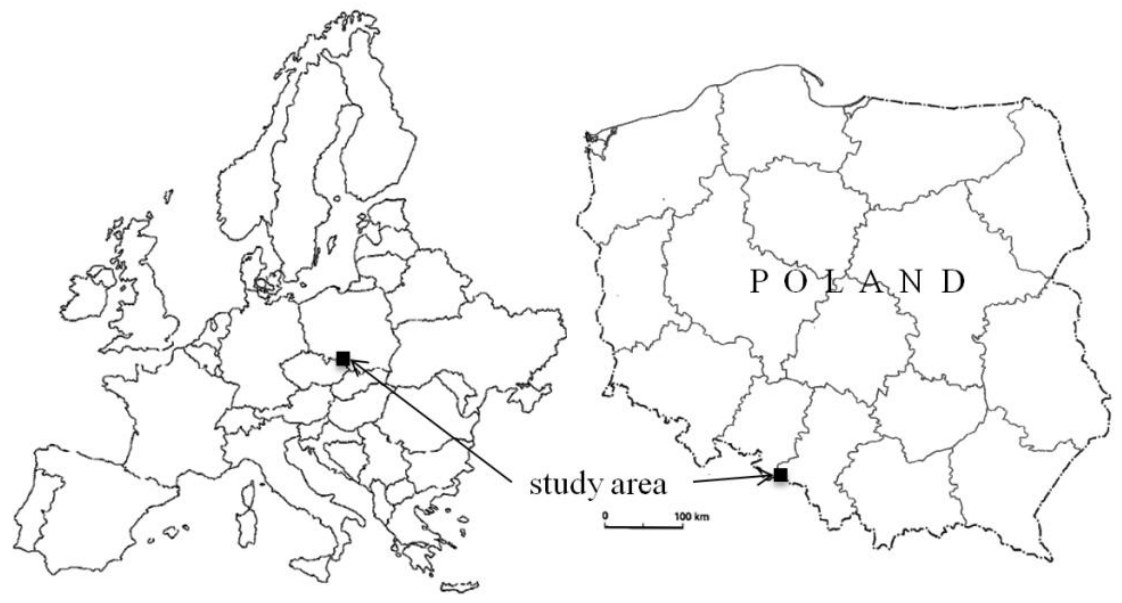

Figure 1. Location of the study area

Table 1. The characteristics of meteorological conditions of the study area

\begin{tabular}{|c|c|c|c|c|c|c|c|c|c|c|c|c|c|}
\hline \multirow{2}{*}{ Period } & \multicolumn{12}{|c|}{ Months } & \\
\hline & I & II & III & IV & V & VI & VII & VIII & IX & $\mathbf{X}$ & $\mathbf{X I}$ & XII & \\
\hline Year & \multicolumn{12}{|c|}{ Average monthly precipitation totals [mm] } & Sum \\
\hline 2012 & 41 & 24 & 18 & 41 & 35 & 75 & 89 & 69 & 58 & 81 & 37 & 18 & 586 \\
\hline 2013 & 44 & 29 & 36 & 21 & 132 & 110 & 14 & 48 & 99 & 24 & 31 & 9 & 597 \\
\hline 2014 & 21 & 16 & 23 & 27 & 137 & 75 & 58 & 92 & 127 & 35 & 18 & 16 & 645 \\
\hline \multirow[t]{2}{*}{ 1971-2000 } & 28 & 26 & 32 & 45 & 67 & 79 & 94 & 74 & 56 & 41 & 40 & 34 & 616 \\
\hline & \multicolumn{12}{|c|}{ Average monthly air temperatures $\left[{ }^{\circ} \mathrm{C}\right]$} & $\begin{array}{c}\text { Average } \\
\text { I-XII }\end{array}$ \\
\hline 2012 & -0.3 & -5.6 & 5.4 & 9.9 & 15.3 & 17.7 & 19.9 & 19.1 & 14.7 & 9.0 & 6.5 & -1.1 & 9.2 \\
\hline 2013 & -2.2 & -0.2 & 0.1 & 9.0 & 13.8 & 16.9 & 19.7 & 19.1 & 12.6 & 10.8 & 5.5 & 2.7 & 9.0 \\
\hline 2014 & 0.6 & 4.0 & 6.9 & 10.8 & 13.8 & 16.3 & 20.4 & 17.4 & 15.6 & 11.1 & 7.1 & 1.6 & 10.5 \\
\hline $1971-2000$ & -1.3 & -0.2 & 3.8 & 8.2 & 13.5 & 16.1 & 17.8 & 17.7 & 13.6 & 9.0 & 3.6 & 0.2 & 8.5 \\
\hline
\end{tabular}

\section{Field analysis}

The field soil tests were carried out in the two agricultural seasons: 2012 and 2013 on arable lands. The alluvial soils are the predominant soil type here on account of height 
of the region's surface water, which makes them good/very good in terms of soil fertility classes.

In field four soil pits were made up to a depth of $150 \mathrm{~cm}$ (Fig. 2; Table 2). Undisturbed soil samples were taken from each genetic horizons using Kopecky's cylinders (in 3 replications) to find the soil water content (SWC), bulk density (BD), total porosity and soil water potential. Also, approximately $1 \mathrm{~kg}$, disturbed soil from each genetic horizons to find the soil texture and other laboratory analysis were taken.
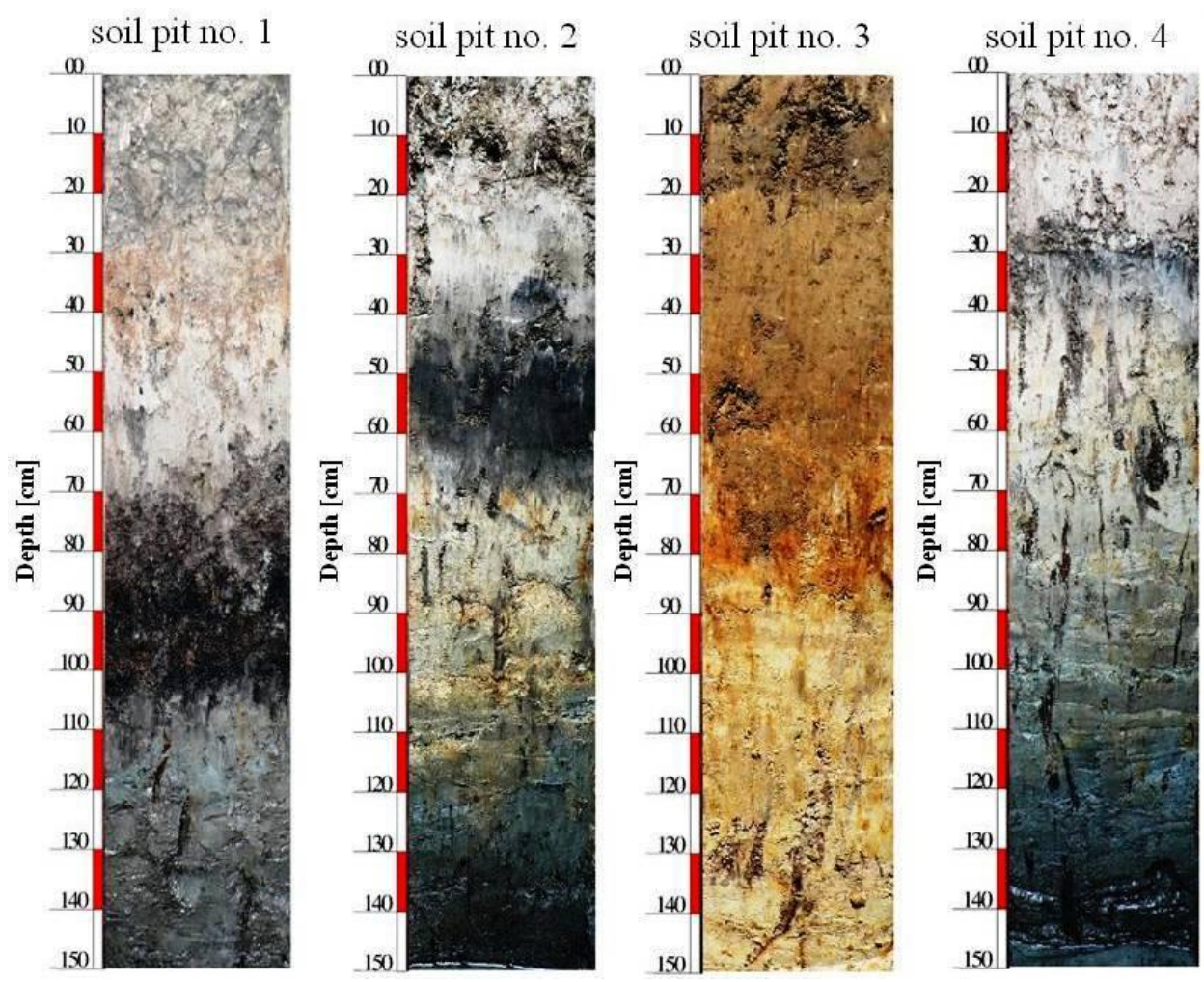

Figure 2. Characteristics of soil pits for the Tworków object

Table 2. Place of soil pits and sampling

\begin{tabular}{c|c|c|c}
\hline \multirow{2}{*}{ Place of soil pits } & \multirow{2}{*}{ Number of soil pits } & \multicolumn{2}{|c}{ Position of soil pits } \\
\cline { 2 - 4 } & 1 & $\mathbf{N}$ & $\mathbf{E}$ \\
\hline \multirow{3}{*}{ Tworków } & 2 & $50^{\circ} 01^{\prime} 02.43^{\prime \prime}$ & $18^{\circ} 14^{\prime} 20.50^{\prime \prime}$ \\
& 3 & $50^{\circ} 01^{\prime} 03.08^{\prime \prime}$ & $18^{\circ} 14^{\prime} 17.87^{\prime \prime}$ \\
& 4 & $50^{\circ} 01^{\prime} 25.47^{\prime \prime}$ & $18^{\circ} 14^{\prime} 25.56^{\prime \prime}$ \\
\hline
\end{tabular}

\section{Laboratory analysis}

From the soil samples that were collected the following properties were determined:

- Soil texture by the Bouyoucose-Casagrande areometric method modified by Prószyński. The modification consisted in measurement of suspension of soil by Prószynski's hydrometer, which gives percentages sedimentation fraction content between the two readings in the time. Suspension density is read in the 


$$
-4685-
$$

terms, which set out in the tables developed by Prószyński. The content of particle size classes (sand, 2.0-0.05 mm; silt, 0.05-0.002 mm; clay, $<0.002 \mathrm{~mm}$ ) is determined according to the Soil Taxonomy system that was made known by the United States Department of Agriculture (USDA) (Soil Survey Staff, 1999).

- Particle density $\left(\rho_{s}\right)$ by the pycnometer method as average density of the mineral grains of the soil (Eq. 1; Mocek and Drzymała, 2010; Phogat et al., 2015):

$$
\rho_{s}=\frac{M_{s}}{V_{s}}\left(\mathrm{~g} \cdot \mathrm{cm}^{-3}\right)
$$

where $M_{s}$ is the mass of mineral grains of the soil sample $(\mathrm{g})$ and $V_{s}$ is the volume of the mineral grains of the soil $\left(\mathrm{cm}^{3}\right)$.

- Soil bulk density $\left(\rho_{b}\right)$ by the gravimetric method in Kopecky's cylinders $\left(100 \mathrm{~cm}^{3}\right)$ as the mass of dry soil per volume. The weight of this soil core is then determined after drying in an oven at $105{ }^{\circ} \mathrm{C}$ for about $18-24 \mathrm{~h}$. The dry bulk density for each core sample was then calculated using equation (Eq. 2; Hao et al., 2008; Phogat et al., 2015):

$$
\rho_{b}=\frac{M_{s}}{V_{t}}\left(\mathrm{~g} \cdot \mathrm{cm}^{-3}\right)
$$

where $M_{s}$ is the mass of dry soil weight $(\mathrm{g})$ and $V_{t}$ is the soil volume $\left(\mathrm{cm}^{3}\right)$.

- Soil moisture (volume wetnees) by the gravimetric method in Kopecky's cylinders $\left(100 \mathrm{~cm}^{3}\right)$ as the ratio of the amount of water in the soil sample to the dry weight of the soil, after drying in an oven at $105^{\circ} \mathrm{C}$ for about $18-24 \mathrm{~h}$, then calculated using Equation 3 (Mocek and Drzymała, 2010; Phogat et al., 2015):

$$
\theta_{v}=\left[\frac{V_{w}}{V_{t}}\right] \cdot 100\left(\mathrm{~cm}^{3} \cdot \mathrm{cm}^{-3}\right)
$$

where $V_{w}$ is the volume of water in the soil sample $\left(\mathrm{cm}^{3}\right)$ and $V_{t}$ is the volume of soil sample $\left(\mathrm{cm}^{3}\right)$.

- Water storage in layer as (Eq. 4; Mocek and Drzymała, 2010):

$$
S_{w}=\frac{\theta_{V} \cdot h}{10}(\mathrm{~mm})
$$

where $\theta_{v}$ is soil moisture $\left(\% \mathrm{~cm}^{3} \cdot \mathrm{cm}^{-3}\right), h$ is thickness of the soil layer $(\mathrm{cm}), 10$ - water conversion from $\mathrm{Mg} \cdot \mathrm{ha}^{-1}$ to $\mathrm{mm}$ water.

- Soil water retention using set for $\mathrm{pF}$ determination with ceramic plates in the 5 and 15 Bar Pressure Plate Extractor. The pressure plate equipment used in this study is made by the American Soil Moisture Equipment Corporation. In engineering practice, soil suction has usually been calculated in $p F$ units (Eq. 5; Schofield, 1935): 


$$
p F=\log h\left(\mathrm{~cm} \mathrm{H}_{2} \mathrm{O}\right)
$$

where $h$ is the suction of water (in $\mathrm{cm}$ ).

In laboratory the soil water potentials were measured at $\mathrm{pF}$ : 0.0, 2.0, 2.2, 2.5, 2.7, 3.0, 3.4, 3.7 and 4.2 (Table 3). The total available water capacity (TAWC) was determined as a difference between the moisture retained at $\mathrm{pF}$ 2.5-4.2. Easily and hardly available water were determined as a difference between the moisture retained at $\mathrm{pF} 2.5-3.7$ and at $\mathrm{pF} 3.7-4.2$, respectively. The field capacity (FC) was considered at $\mathrm{pF}$ 2.5 and the permanent wilting point (PWP) at 4.2 (Mocek and Drzymała, 2010).

Table 3. The pressure applied to determine the $p F$ curves

\begin{tabular}{c|c|c|c|c|c}
\hline $\begin{array}{c}\text { Number of } \\
\text { measurements }\end{array}$ & $\mathbf{p F}$ & $\mathbf{c m} \mathbf{H}_{\mathbf{2}} \mathbf{O}$ & $\mathbf{k P a}$ & $\mathbf{b a r}$ & $\mathbf{m m ~ H g}$ \\
\hline 1 & 0.0 & 0 & 0.00 & 0.0000 & 0.0 \\
2 & 2.0 & 100 & 9.81 & 0.0981 & 73.6 \\
3 & 2.2 & 159 & 15.54 & 0.1554 & 116.6 \\
4 & 2.5 & 316 & 30.99 & 0.3099 & 232.4 \\
5 & 2.7 & 500 & 49.03 & 0.4903 & 367.8 \\
6 & 3.0 & 1000 & 98.07 & 0.9807 & 735.6 \\
7 & 3.4 & 2500 & 245.17 & 2.4517 & 1838.9 \\
8 & 3.7 & 5000 & 490.33 & 4.9033 & 3677.8 \\
9 & 4.2 & 15849 & 1554.26 & 15.5426 & 11657.9 \\
10 & 7.0 & 10000000 & 1000000 & 10000 & 735538.1 \\
\hline
\end{tabular}

- Total organic carbon (TOC) content by the Tiurin's method, then converted to soil organic matter content (SOM) according to the formula (Eq. 6; Mebius, 1960; Mocek and Drzymała, 2010):

$$
S O M=T O C \times 1.724(\%)
$$

- $\mathrm{pH}$ value by means of the potentiometric method in $\mathrm{KCl}$ of $1 \mathrm{~mol} \cdot \mathrm{dm}^{-3}$ concentration in one repetition (Mocek and Drzymała, 2010).

- On the basis of results obtained total porosity was calculated from bulk density and particle density, as (Eq. 7; Mocek and Drzymała, 2010; Phogat et al., 2015):

$$
f=\left[1-\frac{\rho_{b}}{\rho_{s}}\right] \cdot 100(\%)
$$

Soil classification was established according to the Polish Soil Classification (PTG, 2011), the World Reference Base for Soil Resources - IUSS Working Group WRB (2006) and USDA soil taxonomy (Soil Survey Staff, 1999). 


$$
-4687 \text { - }
$$

\section{Modeling the soil water retention in the RETC program}

The RETC (Retention Curve Program) is a computer program which may be used to analyze the soil water retention and hydraulic conductivity functions of unsaturated soils, especially to predict the hydraulic conductivity from observed soil water retention data assuming that one observed conductivity value (not necessarily at saturation) is available (Van Genuchten et al., 1991; Hollenbeck et al., 2000).

The shape of water retention curves $(\mathrm{pF})$ can be characterized by several models, one of them known as the van Genuchten model (1991) (Eq. 8):

$$
\theta_{(h)}=\theta_{r}+\frac{\theta_{s}-\theta_{r}}{\left[1+\left(\alpha|h|^{n}\right)\right]^{m}}
$$

where, $\theta_{(h)}$ is the soil water content $\left(\mathrm{cm}^{3} \cdot \mathrm{cm}^{-3}\right), \theta_{r}$ is the soil residual water content at $\mathrm{pF}>4.2\left(\mathrm{~cm}^{3} \cdot \mathrm{cm}^{-3}\right), \theta_{s}$ is the soil saturated water content at $\mathrm{pF} 0.0\left(\mathrm{~cm}^{3} \cdot \mathrm{cm}^{-3}\right), h$ is soil water potential $(\mathrm{kPa}), \alpha$ is a scale parameter inversely proportional to mean pore diameter $\left(\mathrm{cm}^{-1}\right), n$ and $m$ are the shape parameters of soil water characteristic

$$
m=\frac{1}{n} ; 0<m<1 \text {. }
$$

Retention curves $(\mathrm{pF})$ were compared against those obtained from the RETC program estimations and laboratory measurements. The water retention parameters according to Van Genuchten (1980) with predicted hydraulic functions were estimated by a published neural networks program Rosetta Lite v. 1.1. The necessary input data for the RETC model (e.g. \% soil texture and bulk density) were determined in laboratory analysis of soil samples from different soil horizons (Tables 2, 3 and 4). The unknown parameters $\left(\theta_{\mathrm{s}}, \theta_{\mathrm{r}}, \mathrm{n}, \alpha\right)$ were determined in the RETC program (Van Genuchten et al., 1991) using measured soil water retention data. Rosetta offers five pedotransfer functions (PTFs). To estimate of the water retention parameters $\left(\theta_{\mathrm{r}}, \theta_{\mathrm{s}}, \alpha\right.$, $\mathrm{n}$ ), were used only three of them with limited or more extended sets of predictor. The first model (PTF-1) uses soil textural classes, consisting of a lookup table that provides parameter averages for each USDA textural class. The second model (PTF-2) uses sand, silt, and clay percentages as input, and in contrast to PTF-1, provides hydraulic parameters that vary continuously with texture. The third model (PTF-3) includes bulk density as a predictor (Schaap et al., 1998, 2001).

\section{Statistical analysis}

The data set consisted of analytical results of soil samples collected at the four soil pits located in the Odra River valley during two vegetation seasons (2012 and 2013). For statistical analysis, the procedures provided by the program Statistica PL version 12.5 were used. A 5\% significance level was used. A statistical method was chosen after checking data normality (Shapiro-Wilk test). For each analysed physical and water parameters of soil its minimum and maximum values were determined its arithmetic mean, median, standard deviation (SD) and coefficient of variation (CV) were computed. The performances of the RETC model and laboratory measurements in predicting measured data were assessed using a coefficient of determination $\left(\mathrm{R}^{2}\right)$. 
Moreover, the Spearman's correlation relationship (r) between the granulometric composition and the organic matter of soils and their physical and water values were calculated. The correlation strength and direction of a linear relationship between two variables were determined based on a scale (Rumsey, 2016): exactly \pm 1 - a perfect downhill/uphill (negative/positive) linear relationship; \pm 0.70 - a strong downhill/uphill (negative/positive) linear relationship; $\pm 0.50-$ a moderate downhill/uphill (negative/positive) relationship; \pm 0.30 - a weak downhill/uphill (negative/positive) linear relationship; 0 - no linear relationship.

Table 4. Granulometric composition of soils and basic descriptive statistics

\begin{tabular}{|c|c|c|c|c|c|c|}
\hline \multirow{2}{*}{$\begin{array}{l}\text { Profile } \\
\text { number }\end{array}$} & \multirow{2}{*}{$\begin{array}{l}\text { Depth } \\
(\mathbf{c m})\end{array}$} & \multirow{2}{*}{$\begin{array}{c}\text { Genetic } \\
\text { horizons } \\
\text { (acc. to } P T G)\end{array}$} & \multicolumn{3}{|c|}{$\begin{array}{c}\text { Percentage fraction with diameter } \\
(\mathbf{m m})\end{array}$} & \multirow{2}{*}{$\begin{array}{l}\text { Soil texture group } \\
\text { (acc. to USDA) }\end{array}$} \\
\hline & & & $\begin{array}{c}\text { Sand } \\
2.0-0.05\end{array}$ & $\begin{array}{c}\text { Silt } \\
0.05-0.002\end{array}$ & $\begin{array}{c}\text { Clay } \\
<0.002\end{array}$ & \\
\hline \multirow{5}{*}{1} & $0-30$ & $\mathrm{Ap}$ & 18 & 47 & 35 & \multirow{5}{*}{$\begin{array}{c}\text { Silty clay loam }(\mathrm{SiCL}) \\
\text { Clay }(\mathrm{C}) \\
\text { Clay }(\mathrm{C}) \\
\text { Sandy clay loam }(\mathrm{SCL}) \\
\text { Silty loam }(\mathrm{SiL}) \\
\end{array}$} \\
\hline & $30-46$ & $\mathrm{AC}$ & 31 & 26 & 43 & \\
\hline & $46-63$ & $\mathrm{OCg}$ & 16 & 19 & 65 & \\
\hline & 63-94 & $2 \mathrm{O}$ & 57 & 29 & 14 & \\
\hline & $94-150$ & $3 \mathrm{G}$ & 19 & 62 & 19 & \\
\hline \multirow{5}{*}{2} & $0-18$ & $\overline{A p}$ & 25 & 35 & 40 & \multirow{5}{*}{$\begin{array}{c}\text { Clay loam (CL) } \\
\text { Clay (C) } \\
\text { Loam (L) } \\
\text { Sandy loam (SL) } \\
\text { Sandy loam (SL) }\end{array}$} \\
\hline & $18-34$ & $\mathrm{AC}$ & 18 & 21 & 61 & \\
\hline & $34-52$ & $\mathrm{G}$ & 32 & 44 & 24 & \\
\hline & $52-85$ & $\mathrm{Cg} 1$ & 55 & 33 & 12 & \\
\hline & $85-150$ & $2 \mathrm{G}$ & 76 & 16 & 8 & \\
\hline \multirow{5}{*}{3} & $0-25$ & $\mathrm{Ap}$ & 43 & 35 & 22 & \multirow{5}{*}{$\begin{array}{c}\text { Loam (L) } \\
\text { Loam (L) } \\
\text { Sandy loam (SL) } \\
\text { Loam (L) } \\
\text { Loam (L) }\end{array}$} \\
\hline & $25-47$ & $\mathrm{~A} / \mathrm{Bw}$ & 45 & 33 & 22 & \\
\hline & $47-75$ & $\mathrm{Bw}$ & 58 & 24 & 18 & \\
\hline & $75-117$ & $\mathrm{Cg}$ & 40 & 43 & 17 & \\
\hline & $117-150$ & $2 \mathrm{Cg}$ & 41 & 45 & 14 & \\
\hline \multirow{5}{*}{4} & $0-30$ & Ap & 22 & 40 & 38 & \multirow{5}{*}{$\begin{array}{c}\text { Clay loam }(\mathrm{CL}) \\
\text { Silty clay loam }(\mathrm{SiCL}) \\
\text { Silty loam }(\mathrm{SiL}) \\
\text { Sandy loam }(\mathrm{SL}) \\
\text { Sandy loam }(\mathrm{SL})\end{array}$} \\
\hline & $30-42$ & $\mathrm{O}$ & 17 & 55 & 28 & \\
\hline & $42-71$ & $\mathrm{Bw}$ & 27 & 53 & 20 & \\
\hline & $71-100$ & $\mathrm{Cg}$ & 54 & 33 & 13 & \\
\hline & 100-150 & $2 \mathrm{Cg}$ & 67 & 25 & 8 & \\
\hline \multicolumn{7}{|c|}{ Basic descriptive statistics } \\
\hline \multirow{6}{*}{\multicolumn{2}{|c|}{ Index value: }} & Minimum & 16.0 & 16.0 & 8.0 & \multirow{6}{*}{ 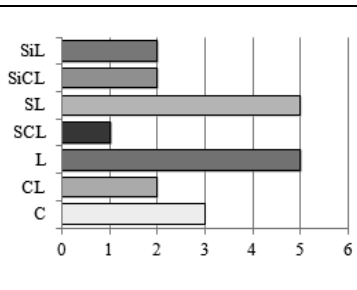 } \\
\hline & & Maximum & 76.0 & 62.0 & 65.0 & \\
\hline & & Mean & 38.0 & 35.9 & 26.1 & \\
\hline & & Median & 36.0 & 34.0 & 21.0 & \\
\hline & & $\mathrm{SD}$ & 18.4 & 12.6 & 16.3 & \\
\hline & & $\mathrm{CV}(\%)$ & 48.2 & 35.1 & 62.4 & \\
\hline
\end{tabular}

\section{Results}

\section{Physical properties of soils}

As shown in Table 4 and Figure 2, the alluvial soils are heterogeneous in terms of texture. In each soil profile, five genetic levels were specified. The granulometric composition of the profiles was classified into to seven soil texture groups (acc. to 
USDA) as: silty loam (SiL), silty clay loam (SiCL), loam (L), sandy clay loam (SCL), sandy loam (SL), clay (C) and clay loam (CL). The high coefficient of variation (CV) values was observed, which is the measure of empirical data deviations from average values. The highest CV was in silt (62.4\%). Sand content in the profiles was between 16 and $76 \%$, silt content between 16 and $62 \%$, and clay content between 8 and $65 \%$. Finally, according to the Polish Soil Classification (PTG, 2011), World Reference Base for Soil Resources - IUSS Working Group WRB (2006) and USDA soil taxonomy (Soil Survey Staff, 1999), examined soils were classified as:

- Order 7. Chernozemic soils (Polish: Gleby czarnoziemne; WRB: Chernozems, Phaeozems; ST: Mollisols - Aquolls, Udolls).

- Type 7.4 "Chernoziemic fluvisols" (Polish: Mady czarnoziemne; WRB: Mollic Fluvisol, Endofluvic Phaeozem; ST: Fluvaquentic Endoaquolls)

The soils formed mostly in recent alluvium on flood plains. Many of the soils have been artificially drained and are used as cropland, but some are used as pasture or forest (Soil Survey Staff, 1999).

The basic physical and chemical properties of soils with descriptive statistics for each sites is given in Table 5.

Table 5. Basic physical and chemical properties of soils and descriptive statistics

\begin{tabular}{|c|c|c|c|c|c|c|c|c|}
\hline \multirow{2}{*}{$\begin{array}{c}\text { Profile } \\
\text { number }\end{array}$} & Depth & $\begin{array}{c}\text { Soil } \\
\text { moisture }\end{array}$ & $\begin{array}{c}\text { Bulk } \\
\text { density }\end{array}$ & $\begin{array}{l}\text { Particle } \\
\text { density }\end{array}$ & \begin{tabular}{|c|} 
Total \\
porosity
\end{tabular} & $\begin{array}{c}\text { Soil organic } \\
\text { matter }\end{array}$ & \multirow{2}{*}{$\begin{array}{c}\mathbf{p H} \\
(\mathrm{KCl})\end{array}$} & $\begin{array}{c}\text { Water storage } \\
\text { in layer }\end{array}$ \\
\hline & (cm) & $\left(\mathrm{cm}^{3} \cdot \mathrm{cm}^{-3}\right)$ & \multicolumn{2}{|c|}{$\left(\mathrm{g} \cdot \mathrm{cm}^{-3}\right)$} & \multicolumn{2}{|c|}{$(\%)$} & & $(\mathbf{m m})$ \\
\hline \multirow{5}{*}{1} & $0-30$ & 0.3087 & 1.44 & 2.53 & 43.08 & 3.7 & 6.29 & 93 \\
\hline & $30-46$ & 0.4644 & 1.12 & 2.62 & 57.25 & 2.4 & 6.22 & 74 \\
\hline & $46-63$ & 0.4844 & 1.06 & 2.43 & 56.38 & 4.0 & 6.02 & 82 \\
\hline & $63-94$ & 0.6684 & 0.44 & 1.69 & 73.96 & 7.5 & 5.61 & 207 \\
\hline & $94-150$ & 0.4622 & 1.40 & 2.63 & 46.77 & 1.8 & 7.27 & 259 \\
\hline \multirow{5}{*}{2} & $0-18$ & 0.4016 & 1.32 & 2.54 & 48.03 & 3.3 & 6.59 & 72 \\
\hline & $18-34$ & 0.4247 & 1.29 & 2.56 & 49.61 & 2.3 & 6.45 & 68 \\
\hline & $34-52$ & 0.3740 & 1.52 & 2.57 & 40.86 & 2.2 & 6.67 & 67 \\
\hline & $52-85$ & 0.3363 & 1.75 & 2.64 & 33.71 & 0.7 & 6.61 & 111 \\
\hline & $85-150$ & 0.3941 & 1.61 & 2.63 & 38.78 & 1.1 & 3.71 & 256 \\
\hline \multirow{5}{*}{3} & $0-25$ & 0.2734 & 1.65 & 2.53 & 34.78 & 1.8 & 5.83 & 68 \\
\hline & $25-47$ & 0.2330 & 1.81 & 2.66 & 31.95 & 1.0 & 6.16 & 51 \\
\hline & $47-75$ & 0.3197 & 1.66 & 2.68 & 38.06 & 0.4 & 6.40 & 90 \\
\hline & $75-117$ & 0.3500 & 1.68 & 2.70 & 37.78 & 0.3 & 6.42 & 147 \\
\hline & $117-150$ & 0.3678 & 1.68 & 2.67 & 37.08 & 0.2 & 6.29 & 121 \\
\hline \multirow{5}{*}{4} & $0-30$ & 0.5145 & 1.11 & 2.56 & 56.64 & 4.0 & 6.49 & 154 \\
\hline & $30-42$ & 0.3943 & 1.51 & 2.48 & 39.11 & 1.9 & 6.53 & 47 \\
\hline & $42-71$ & 0.4028 & 1.56 & 2.65 & 41.13 & 0.7 & 6.37 & 117 \\
\hline & $71-100$ & 0.3241 & 1.65 & 2.67 & 38.20 & 0.4 & 6.53 & 94 \\
\hline & $100-150$ & 0.3159 & 1.62 & 2.69 & 39.78 & 0.8 & 4.95 & 158 \\
\hline \multicolumn{9}{|c|}{ Basic descriptive statistics } \\
\hline \multirow{6}{*}{$\begin{array}{l}\text { Index } \\
\text { value: }\end{array}$} & Minimum & 0.2330 & 0.44 & 1.69 & 31.95 & 0.2 & 3.71 & 47 \\
\hline & Maximum & 0.6684 & 1.81 & 2.70 & 73.96 & 7.5 & 7.27 & 259 \\
\hline & Mean & 0.3907 & 1.44 & 2.56 & 44.15 & 2.0 & 6.17 & 117 \\
\hline & Median & 0.3841 & 1.54 & 2.63 & 40.32 & 1.8 & 6.39 & 94 \\
\hline & $\mathrm{SD}$ & 9.71 & 0.32 & 0.22 & 10.31 & 1.8 & 0.74 & 63 \\
\hline & $\mathrm{CV}(\%)$ & 24.85 & 22.27 & 8.49 & 23.36 & 88.54 & 12.02 & 53.81 \\
\hline
\end{tabular}


High soil moisture values were observed in soil profiles. The average soil moisture content was $0.3907 \mathrm{~cm}^{3} \cdot \mathrm{cm}^{-3}$, which means it is very close to average value of water content at the field's water capacity (Table 6). Bulk density (BD) was in range 0.44$1.81 \mathrm{~g} \cdot \mathrm{cm}^{-3}$ and predominantly increasing with a depth and yielding a very high value for total porosity from $31.95 \%$ to $73.96 \%$. Mean particle density value is very similar in whole profiles about $2.56 \mathrm{~g} \cdot \mathrm{cm}^{-3}$, only in profile no. 1 in fourth genetic horizon (rich in organic matter) it is much smaller $\left(1.69 \mathrm{~g} \cdot \mathrm{cm}^{-3}\right)$. According to coefficient of variation $(\mathrm{CV})$, the behaviour in the soil profiles can be considered as a low variability (see Table 5). Mean organic matter content, about $2.03 \%$, was highest in top layers and decreasing with depth. The $\mathrm{pH}$ values were in a wide range from 3.71 to 7.27 , which corresponds to very acidic to alkaline soils. The high values of water storage ranged $477-715 \mathrm{~mm}$ in soil profiles was observed.

Table 6. Retention of available water in soil

\begin{tabular}{|c|c|c|c|c|c|c|c|}
\hline \multirow{3}{*}{$\begin{array}{l}\text { Profile } \\
\text { number }\end{array}$} & \multirow{3}{*}{$\begin{array}{l}\text { Depth } \\
{[\mathrm{cm}]}\end{array}$} & $\begin{array}{l}\text { Maximum } \\
\text { retentive } \\
\text { capacity }\end{array}$ & $\begin{array}{c}\text { Field water } \\
\text { capacity }\end{array}$ & $\begin{array}{l}\text { Permanent } \\
\text { wilting } \\
\text { point }\end{array}$ & $\begin{array}{l}\text { Available } \\
\text { water for } \\
\text { plants }\end{array}$ & $\begin{array}{c}\text { Easily } \\
\text { accessible } \\
\text { water }\end{array}$ & $\begin{array}{c}\text { Hardly } \\
\text { accessible } \\
\text { water }\end{array}$ \\
\hline & & pF 0.0 & pF 2.5 & pF 4.2 & pF 2.5-4.2 & pF 2.5-3.7 & pF 3.7-4.2 \\
\hline & & \multicolumn{6}{|c|}{$\left(\mathrm{cm}^{3} \cdot \mathrm{cm}^{-3}\right)$} \\
\hline \multirow{5}{*}{1} & $0-30$ & 0.4995 & 0.4289 & 0.2690 & 0.1599 & 0.0529 & 0.1070 \\
\hline & $30-46$ & 0.5618 & 0.5280 & 0.3166 & 0.2114 & 0.1235 & 0.0879 \\
\hline & $46-63$ & 0.6242 & 0.6119 & 0.3314 & 0.2805 & 0.2247 & 0.0558 \\
\hline & 63-94 & 0.7936 & 0.6784 & 0.3092 & 0.3692 & 0.3437 & 0.0255 \\
\hline & $94-150$ & 0.5203 & 0.4894 & 0.1915 & 0.2979 & 0.2877 & 0.0102 \\
\hline \multirow{5}{*}{2} & $0-18$ & 0.5117 & 0.4759 & 0.2466 & 0.2293 & 0.0808 & 0.1485 \\
\hline & $18-34$ & 0.5282 & 0.5177 & 0.2894 & 0.2283 & 0.1486 & 0.0797 \\
\hline & $34-52$ & 0.4687 & 0.4502 & 0.2557 & 0.1945 & 0.1150 & 0.0795 \\
\hline & $52-85$ & 0.4080 & 0.3556 & 0.1327 & 0.2229 & 0.1839 & 0.0390 \\
\hline & $85-150$ & 0.4253 & 0.3467 & 0.1034 & 0.2433 & 0.2145 & 0.0288 \\
\hline \multirow{5}{*}{3} & $0-25$ & 0.4052 & 0.3770 & 0.2500 & 0.1270 & 0.1214 & 0.0056 \\
\hline & $25-47$ & 0.3211 & 0.2985 & 0.1503 & 0.1482 & 0.0879 & 0.0603 \\
\hline & $47-75$ & 0.3823 & 0.3345 & 0.1576 & 0.1769 & 0.1465 & 0.0304 \\
\hline & $75-117$ & 0.3689 & 0.3484 & 0.1306 & 0.2178 & 0.1858 & 0.0320 \\
\hline & $117-150$ & 0.3962 & 0.3417 & 0.0886 & 0.2531 & 0.2135 & 0.0396 \\
\hline \multirow{5}{*}{4} & $0-30$ & 0.5760 & 0.5663 & 0.2943 & 0.2720 & 0.1764 & 0.0956 \\
\hline & $30-42$ & 0.4514 & 0.4386 & 0.2870 & 0.1516 & 0.1304 & 0.0212 \\
\hline & $42-71$ & 0.4394 & 0.4225 & 0.1873 & 0.2352 & 0.2131 & 0.0221 \\
\hline & $71-100$ & 0.3948 & 0.2690 & 0.0737 & 0.1953 & 0.1352 & 0.0601 \\
\hline & $100-150$ & 0.4314 & 0.3094 & 0.0649 & 0.2445 & 0.2442 & 0.0003 \\
\hline \multicolumn{8}{|c|}{ Basic descriptive statistics } \\
\hline \multirow{6}{*}{$\begin{array}{l}\text { Index } \\
\text { value }\end{array}$} & Minimum & 0.3211 & 0.2690 & 0.0649 & 0.1270 & 0.0529 & 0.0003 \\
\hline & Maximum & 0.7936 & 0.6784 & 0.3314 & 0.3692 & 0.3437 & 0.1485 \\
\hline & Mean & 0.4754 & 0.4294 & 0.2065 & 0.2229 & 0.1715 & 0.0515 \\
\hline & Median & 0.4454 & 0.4257 & 0.2191 & 0.2256 & 0.1625 & 0.0393 \\
\hline & SD & 0.11 & 0.11 & 0.08 & 0.06 & 0.07 & 0.04 \\
\hline & CV (\%) & 22.64 & 25.81 & 42.84 & 25.72 & 41.97 & 74.66 \\
\hline
\end{tabular}




$$
-4691 \text { - }
$$

\section{Hydraulic properties of soils}

The data of soil water retention, incuded available water for plants, from laboratory analysis are presented in Table 6. The water retention curve for the studied soils showed a mean value of soil moisture of about $0.4754 \mathrm{~cm}^{3} \cdot \mathrm{cm}^{-3}$ at saturation $(\mathrm{pF} 0.0)$, $0.4294 \mathrm{~cm}^{3} \cdot \mathrm{cm}^{-3}$ at field water capacity $(\mathrm{pF} 2.5)$, and $0.2065 \mathrm{~cm}^{3} \cdot \mathrm{cm}^{-3}$ at permanent wilting point ( $\mathrm{pF} 4.2$ ). Mean share of easily accessible water for plants contributed $77 \%$ of the total available water for plants (TAWC), whereas hardly accessible water accounted $23 \%$ TAWC.

The determination coefficient $\left(\mathrm{R}^{2}\right)$ of observed and fitted values in each layers of soil profiles ranges from 0.825 to 0.995 . These results are very satisfactory and show that the estimation procedure works well (Tables 7, 8 and 9). Tables 7, 8 and 9 present different values of the van Genuchten parameters $\left(\theta_{r}, \theta_{s}, \alpha, n\right)$ obtained.

Table 7. Characteristic parameters of soil water content from model PTF-1 with soil USDA textural classes

\begin{tabular}{c|c|c|c|c|c|c}
\hline $\begin{array}{c}\text { Profile } \\
\text { number }\end{array}$ & $\begin{array}{c}\text { Depth } \\
{[\mathbf{c m}]}\end{array}$ & $\begin{array}{c}\boldsymbol{\theta}_{\mathbf{r}} \\
\left(\mathbf{c m}^{\mathbf{3}} \cdot \mathbf{c m}^{-\mathbf{3}}\right)\end{array}$ & $\begin{array}{c}\boldsymbol{\theta}_{\mathbf{s}} \\
\left(\mathbf{c m}^{3} \cdot \mathbf{c m}^{-\mathbf{3}}\right)\end{array}$ & $\begin{array}{c}\boldsymbol{\alpha} \\
\left(\mathbf{c m}^{-\mathbf{1}}\right)\end{array}$ & $\begin{array}{c}\mathbf{n} \\
(-)\end{array}$ & $\mathbf{R}^{\mathbf{2}}$ \\
\hline \multirow{4}{*}{1} & $0-30$ & 0.0901 & 0.4820 & 0.0084 & 1.5202 & 0.978 \\
& $30-46$ & 0.0982 & 0.4588 & 0.0150 & 1.2529 & 0.993 \\
& $46-63$ & 0.0982 & 0.4588 & 0.0150 & 1.2529 & 0.987 \\
& $63-94$ & 0.0633 & 0.3837 & 0.0211 & 1.3298 & 0.979 \\
& $94-150$ & 0.0645 & 0.4387 & 0.0051 & 1.6626 & 0.955 \\
\hline \multirow{3}{*}{2} & $0-18$ & 0.0792 & 0.4418 & 0.0158 & 1.4145 & 0.825 \\
& $18-34$ & 0.0982 & 0.4588 & 0.0150 & 1.2529 & 0.995 \\
& $34-52$ & 0.0609 & 0.3991 & 0.0111 & 1.4737 & 0.989 \\
& $52-85$ & 0.0387 & 0.3870 & 0.0267 & 1.4484 & 0.979 \\
& $85-150$ & 0.0387 & 0.3870 & 0.0267 & 1.4484 & 0.965 \\
\hline \multirow{4}{*}{3} & $0-25$ & 0.0609 & 0.3991 & 0.0111 & 1.4737 & 0.969 \\
& $25-47$ & 0.0609 & 0.3991 & 0.0111 & 1.4737 & 0.989 \\
& $47-75$ & 0.0387 & 0.3870 & 0.0267 & 1.4484 & 0.985 \\
& $75-117$ & 0.0609 & 0.3991 & 0.0111 & 1.4737 & 0.987 \\
& $117-150$ & 0.0609 & 0.3991 & 0.0111 & 1.4737 & 0.979 \\
\hline \multirow{3}{*}{4} & $0-30$ & 0.0792 & 0.4418 & 0.0158 & 1.4145 & 0.995 \\
& $30-42$ & 0.0901 & 0.4820 & 0.0084 & 1.5202 & 0.979 \\
& $42-71$ & 0.0645 & 0.4387 & 0.0051 & 1.6626 & 0.981 \\
& $71-100$ & 0.0387 & 0.3870 & 0.0267 & 1.4484 & 0.978 \\
& $100-150$ & 0.0387 & 0.3870 & 0.0267 & 1.4484 & 0.956 \\
\hline
\end{tabular}

Table 8. Characteristic parameters of soil water content from model PTF-2 with \% sand, silt, and clay

\begin{tabular}{c|c|c|c|c|c|c}
\hline $\begin{array}{c}\text { Profile } \\
\text { number }\end{array}$ & $\begin{array}{c}\text { Depth } \\
\mathbf{[ \mathbf { c m } ]}\end{array}$ & $\begin{array}{c}\boldsymbol{\theta}_{\mathbf{r}} \\
\left(\mathbf{c m}^{\mathbf{3}} \cdot \mathbf{c m}^{-\mathbf{3}}\right)\end{array}$ & $\begin{array}{c}\boldsymbol{\theta}_{\mathbf{s}} \\
\left(\mathbf{c m}^{\mathbf{3}} \cdot \mathbf{c m}^{-\mathbf{3}}\right)\end{array}$ & $\begin{array}{c}\boldsymbol{\alpha} \\
\left(\mathbf{c m}^{-\mathbf{1}}\right)\end{array}$ & $\begin{array}{c}\mathbf{n} \\
(-)\end{array}$ & $\mathbf{R}^{\mathbf{2}}$ \\
\hline & $0-30$ & 0.0891 & 0.4665 & 0.0096 & 1.4593 & 0.978 \\
& $30-46$ & 0.0886 & 0.4484 & 0.0184 & 1.2893 & 0.993 \\
1 & $46-63$ & 0.0990 & 0.4950 & 0.0209 & 1.1936 & 0.987 \\
& $63-94$ & 0.0493 & 0.3884 & 0.0217 & 1.4033 & 0.979 \\
& $94-150$ & 0.0683 & 0.4340 & 0.0048 & 1.6502 & 0.955 \\
\hline
\end{tabular}




\begin{tabular}{c|c|c|c|c|c|c}
\hline & $0-18$ & 0.0893 & 0.4586 & 0.0136 & 1.3573 & 0.825 \\
2 & $18-34$ & 0.0979 & 0.4899 & 0.0205 & 1.2075 & 0.995 \\
& $34-52$ & 0.0710 & 0.4228 & 0.0080 & 1.5222 & 0.989 \\
& $52-85$ & 0.0456 & 0.3889 & 0.0189 & 1.4229 & 0.979 \\
& $85-150$ & 0.0417 & 0.3841 & 0.0386 & 1.5283 & 0.965 \\
\hline \multirow{4}{*}{3} & $0-25$ & 0.0656 & 0.4064 & 0.0128 & 1.4469 & 0.969 \\
& $25-47$ & 0.0654 & 0.4042 & 0.0144 & 1.4294 & 0.989 \\
& $47-75$ & 0.0564 & 0.3888 & 0.0240 & 1.3761 & 0.985 \\
& $75-117$ & 0.0574 & 0.4019 & 0.0084 & 1.5280 & 0.987 \\
& $117-150$ & 0.0518 & 0.3992 & 0.0079 & 1.5455 & 0.979 \\
\hline \multirow{4}{*}{4} & $0-30$ & 0.0896 & 0.4631 & 0.0117 & 1.4001 & 0.995 \\
& $30-42$ & 0.0812 & 0.4516 & 0.0068 & 1.5501 & 0.979 \\
& $42-71$ & 0.0664 & 0.4215 & 0.0054 & 1.6101 & 0.981 \\
& $71-100$ & 0.0477 & 0.3894 & 0.0181 & 1.4251 & 0.978 \\
& $100-150$ & 0.0380 & 0.3876 & 0.0355 & 1.4168 & 0.956 \\
\hline
\end{tabular}

Table 9. Characteristic parameters of soil water content from model PTF-3 with \% sand, silt, clay and bulk density $(B D)$

\begin{tabular}{|c|c|c|c|c|c|c|}
\hline $\begin{array}{l}\text { Profile } \\
\text { number }\end{array}$ & $\begin{array}{c}\text { Depth } \\
{[\mathrm{cm}]}\end{array}$ & $\begin{array}{c}\theta_{\mathbf{r}} \\
\left(\mathrm{cm}^{3} \cdot \mathbf{c m}^{-3}\right)\end{array}$ & $\begin{array}{c}\theta_{\mathrm{s}} \\
\left(\mathrm{cm}^{3} \cdot \mathbf{c m}^{-3}\right)\end{array}$ & $\begin{array}{c}\alpha \\
\left(\mathbf{c m}^{-1}\right)\end{array}$ & $\begin{array}{l}\mathbf{n} \\
(-)\end{array}$ & $\mathbf{R}^{2}$ \\
\hline \multirow{5}{*}{1} & $0-30$ & 0.0978 & 0.5650 & 0.0112 & 1.4528 & 0.978 \\
\hline & $30-46$ & 0.1035 & 0.5774 & 0.0195 & 1.3542 & 0.993 \\
\hline & $46-63$ & 0.1146 & 0.6102 & 0.0282 & 1.2495 & 0.987 \\
\hline & 63-94 & \multicolumn{5}{|c|}{ indicates the parameter cannot be estimated (too low bulk density value) } \\
\hline & 94-150 & 0.0780 & 0.5163 & 0.0046 & 1.6932 & 0.955 \\
\hline \multirow{5}{*}{2} & $0-18$ & 0.1014 & 0.5727 & 0.0156 & 1.3894 & 0.825 \\
\hline & $18-34$ & 0.1130 & 0.6064 & 0.0271 & 1.2618 & 0.995 \\
\hline & $34-52$ & 0.0807 & 0.5199 & 0.0073 & 1.5678 & 0.989 \\
\hline & $52-85$ & 0.0535 & 0.4896 & 0.0115 & 1.4812 & 0.979 \\
\hline & $85-150$ & 0.0475 & 0.5235 & 0.0353 & 1.4232 & 0.965 \\
\hline \multirow{5}{*}{3} & $0-25$ & 0.0753 & 0.5160 & 0.0094 & 1.5163 & 0.969 \\
\hline & $25-47$ & 0.0749 & 0.5178 & 0.0102 & 1.5004 & 0.989 \\
\hline & $47-75$ & 0.0658 & 0.5208 & 0.0159 & 1.4322 & 0.985 \\
\hline & $75-117$ & 0.0663 & 0.4917 & 0.0063 & 1.6010 & 0.987 \\
\hline & $117-150$ & 0.0602 & 0.4791 & 0.0058 & 1.6215 & 0.979 \\
\hline \multirow{5}{*}{4} & $0-30$ & 0.1000 & 0.5696 & 0.0137 & 1.4136 & 0.995 \\
\hline & $30-42$ & 0.0897 & 0.5450 & 0.0073 & 1.5529 & 0.979 \\
\hline & $42-71$ & 0.0757 & 0.5068 & 0.0051 & 1.6576 & 0.981 \\
\hline & 71-100 & 0.0577 & 0.4921 & 0.0111 & 1.4871 & 0.978 \\
\hline & $100-150$ & 0.0454 & 0.5010 & 0.0231 & 1.4086 & 0.956 \\
\hline
\end{tabular}

The graphs of the fitted the van Genuchten model with the RETC to the soil water retention data with laboratory measurements for soil pit no. 1 - from depth of 0-30 cm and for soil pit no. 2 - from depth of 34-52 cm are illustrated in Figure 3, as examples. It is observed that both the results of research fit well. 


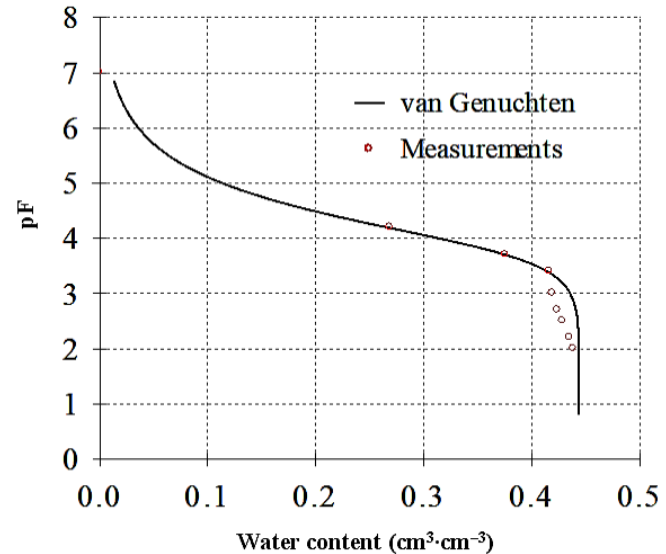

(a)

Figure 3. Water retention curve $(p F)$ : a) - soil pit no. 1 ; $b$ ) - soil pit no. 2

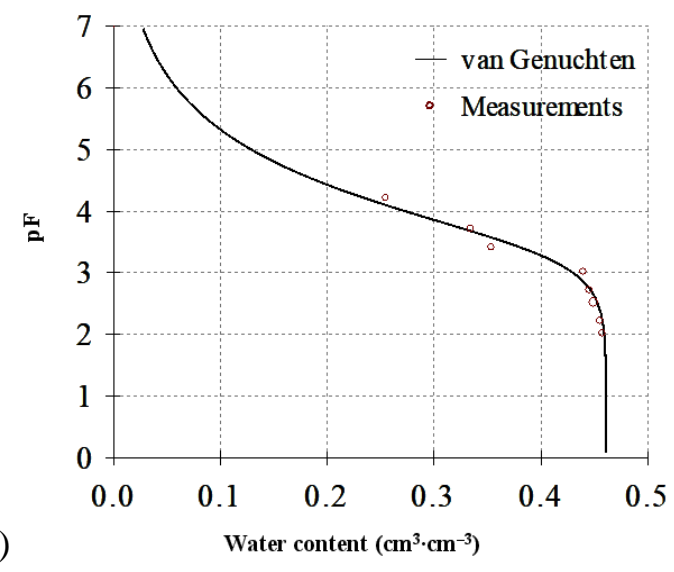

(b) s

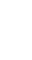


(a)

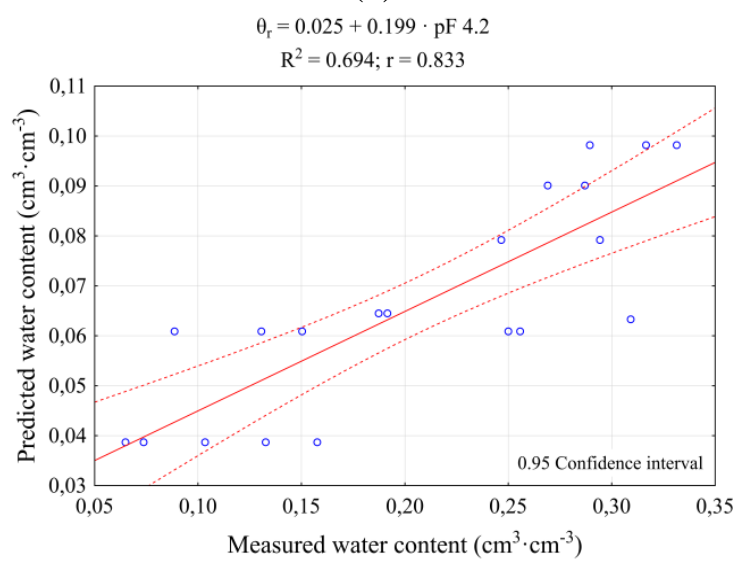

(b)

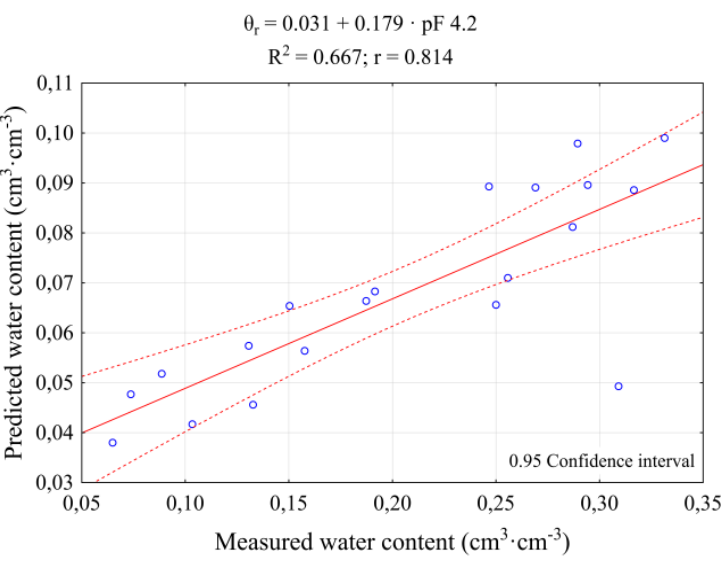

(c)

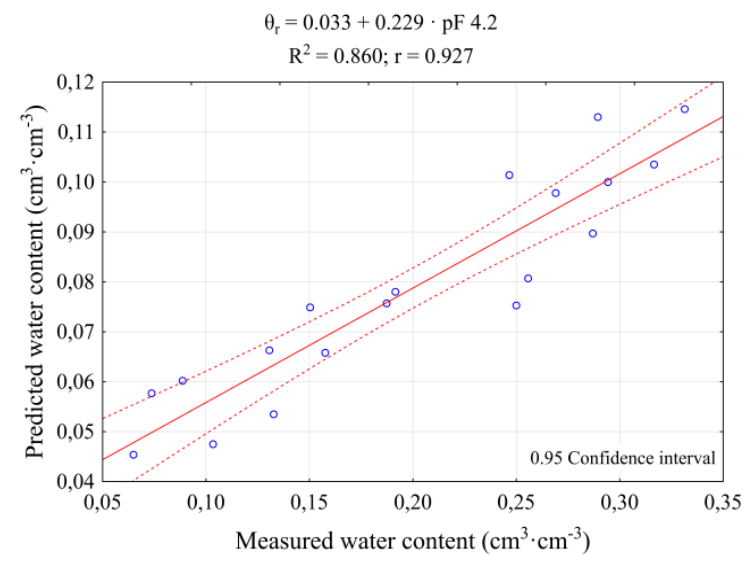

Figure 5. Estimated vs. measured water contents $(\theta r)$ of the RETC a) for first model (PTF-1), $b$ ) second model (PTF-2), c) for third model (PTF-3)

The results of the three pedotransfer functions show statistically increase in the $\mathrm{R}^{2}$ for $\theta_{\mathrm{r}}\left(\mathrm{PTF}-1-\mathrm{R}^{2}=0.694, \mathrm{p}<0.05\right.$; PTF- $2-\mathrm{R}^{2}=0.667, \mathrm{p}<0.05$ and for PTF-3 $\left.\mathrm{R}^{2}=0.860, \mathrm{p}<0.05\right)$. On the other hand two neural network models show statistically low $\mathrm{R}^{2}$ and also no statistically significant for $\theta_{\mathrm{s}}\left(\mathrm{PTF}-1-\mathrm{R}^{2}=0.101, \mathrm{p}>0.05\right.$ and for PTF-2 $\left.-\mathrm{R}^{2}=0.181, \mathrm{p}>0.05\right)$ only in case of PTF-3 results was high and statistically significant $\left(\mathrm{R}^{2}=0.667, \mathrm{p}<0.05\right)$.

In order to find interrelations of soil properties a correlation R Spearman analysis was conducted. The correlation (Table 10) displayed significant correlation between particle size distribution (i.e. sand, silt, clay content) and soil organic matter (SOM) content, and physical and water properties of soil.

Sand content was statistically significance $(\mathrm{p}<0.05)$ negatively correlated with field capacity (FC), hardly accessible water and $\mathrm{pH}$, whereas silt content was statistically significance positively correlated with $\mathrm{pH}$. Also clay content was statistically significance positively correlated with FC and hardly accessible water. Soil organic matter was statistically significance positively correlated with water content, total porosity, FC and available water but statistically significance negatively correlated with BD and particle density. The correlation strength between SOM and soil moisture, BD, 
particle density, total porosity and FC was statistically very high ( $\mathrm{r}>0.7)$, while between SOM and available water was statistically high $(0.5<\mathrm{r}<0.7)$.

Table 10. Correlation coefficient ( $r$ ) between the granulometric composition and organic matter of soils and selected physical and water properties

\begin{tabular}{|c|c|c|c|c|}
\hline Variables: & Percentage & action with $\mathrm{d}$ & neter $(\mathbf{m m})$ & \\
\hline Physical and water properties of soils: & $\begin{array}{c}\text { Sand } \\
2.0-0.05\end{array}$ & $\begin{array}{c}\text { Silt } \\
0.05-0.002\end{array}$ & $\begin{array}{c}\text { Clay } \\
<0.002\end{array}$ & $(\%)$ \\
\hline Water content $\left(\% \mathrm{~cm}^{3} \cdot \mathrm{cm}^{-3}\right)$ & $\begin{array}{c}r=-0.2134 \\
p=0.366\end{array}$ & $\begin{array}{c}\mathrm{r}=-0.0488 \\
\mathrm{p}=0.838\end{array}$ & $\begin{array}{c}\mathrm{r}=0.2785 \\
\mathrm{p}=0.235\end{array}$ & $\begin{array}{r}r=0.7597^{*} \\
p=0.000\end{array}$ \\
\hline Bulk density $\left(\mathrm{g} \cdot \mathrm{cm}^{-3}\right)$ & $\begin{array}{c}\mathrm{r}=0.2540 \\
\mathrm{p}=0.280\end{array}$ & $\begin{array}{c}r=0.1771 \\
p=0.455\end{array}$ & $\begin{array}{c}r=-0.4236 \\
p=0.063\end{array}$ & $\begin{array}{c}r=-0.9220 \\
p=0.000\end{array}$ \\
\hline Particle density $\left(\mathrm{g} \cdot \mathrm{cm}^{-3}\right)$ & $\begin{array}{c}\mathrm{r}=-0.0108 \\
\mathrm{p}=0.964\end{array}$ & $\begin{array}{l}\mathrm{r}=0.1185 \\
\mathrm{p}=0.619\end{array}$ & $\begin{array}{c}r=-0.0795 \\
p=0.739\end{array}$ & $\begin{array}{c}r=\mathbf{- 0 . 8 7 0 7} \\
p=0.000\end{array}$ \\
\hline Total porosity $\left(\% \mathrm{~cm}^{3} \cdot \mathrm{cm}^{-3}\right)$ & $\begin{array}{c}r=-0.2545 \\
p=0.279\end{array}$ & $\begin{array}{c}\mathrm{r}=-0.1965 \\
\mathrm{p}=0.406\end{array}$ & $\begin{array}{c}\mathrm{r}=0.4392 \\
\mathrm{p}=0.053\end{array}$ & $\begin{array}{c}r=0.8747 \\
p=0.000\end{array}$ \\
\hline $\mathrm{pH}(-)$ & $\begin{array}{c}r=-0.6649 \\
p=0.001\end{array}$ & $\begin{array}{c}r=0.6055 \\
p=0.005\end{array}$ & $\begin{array}{c}\mathrm{r}=0.2810 \\
\mathrm{p}=0.230\end{array}$ & $\begin{array}{c}\mathrm{r}=-0.0278 \\
\mathrm{p}=0.907\end{array}$ \\
\hline Field capacity (pF 2.5) & $\begin{array}{c}r=-\mathbf{0 . 5 1 3 8} \\
\mathbf{p}=\mathbf{0 . 0 2 0}\end{array}$ & $\begin{array}{c}r=-0.0367 \\
p=0.878\end{array}$ & $\begin{array}{c}r=0.6079 \\
p=0.004\end{array}$ & $\begin{array}{c}r=0.8723 \\
p=0.000\end{array}$ \\
\hline Available water ( $\mathrm{pF}$ 2.5-4.2) & $\begin{array}{l}\mathrm{r}=0.0551 \\
\mathrm{p}=0.817\end{array}$ & $\begin{array}{c}r=-0.0984 \\
p=0.680\end{array}$ & $\begin{array}{c}\mathrm{r}=0.0140 \\
\mathrm{p}=0.953\end{array}$ & $\begin{array}{c}r=0.5163 \\
p=0.020\end{array}$ \\
\hline Easily accessible water (pF 2.5-3.7) & $\begin{array}{l}\mathrm{r}=0.2828 \\
\mathrm{p}=0.227\end{array}$ & $\begin{array}{c}\mathrm{r}=-0.0287 \\
\mathrm{p}=0.904\end{array}$ & $\begin{array}{c}r=-0.2968 \\
p=0.204\end{array}$ & $\begin{array}{c}\mathrm{r}=0.2377 \\
\mathrm{p}=0.313\end{array}$ \\
\hline Hardly accessible water (pF 3.7-4.2) & $\begin{array}{c}r=-0.4477 \\
p=0.048\end{array}$ & $\begin{array}{c}\mathrm{r}=-0.0931 \\
\mathrm{p}=0.696\end{array}$ & $\begin{array}{c}r=0.5770 \\
p=0.008\end{array}$ & $\begin{array}{c}\mathrm{r}=0.3251 \\
\mathrm{p}=0.162\end{array}$ \\
\hline
\end{tabular}

$*$ Values in bold indicate that correlation relationships are statistically significant $(\mathrm{p}<0.05)$

\section{Discussion}

The examined alluvial soils are very specified and diversity in terms of texture (Iqbal et al., 2005; Bullinger-Weber et al., 2007; Luptáčik et al., 2012) and showed high water content values (at saturation $0.4754 \mathrm{~cm}^{3} \cdot \mathrm{cm}^{-3}$ and wilting point $0.2065 \mathrm{~cm}^{3} \cdot \mathrm{cm}^{-3}$ ). This feature may be related to the high silt (35.9\%) and clay (26.1\%) for all soil profiles and also mean organic matter content about 2.03\% (Rawls et al., 2003; Rubio and Poyatos, 2012). Minasny et al. (2003) reported. that the hydraulic parameters are mostly sensitive to sand content and saturated water content. Gama-Castro et al. (2000) found, that the high productivity of alluvial soils is largely due to the plant available water. According to Hong et al. (2013) the most important values for agricultural use is a field water capacity (at $\mathrm{pF} 2.5$ ), which in this case ranged between 0.2690 and $0.6784 \mathrm{~cm}^{3} \cdot \mathrm{cm}^{-3}$.

The maximum retentive capacity (at $\mathrm{pF} 0.0$ ) measured in laboratory was slightly different than total porosity calculated from bulk density and particle density. Paluszek (2011) stated that the difference between maximum retentive capacity and total porosity may be especially visible in the soils with high content of swelling clay minerals because maximum retentive capacity was directly determined after capillary rise to the 
state of full saturation, while total porosity was calculated on the basis of the particle density and bulk density.

Bulk density (BD) is one of important physical soil properties that characterizes soil compaction (Reynolds et al., 2002). The BD range of alluvial soils can be very wide smaller values were observed in the Ap horizons and increased with depth (GamaCastro et al., 2000). We observed that bulk density was related to organic matter contents, which is not in agreement with the findings of Gama-Castro et al. (2000), where they assumed that the presence of more noncrystalline material due to increased pumice weathering contributes to the low bulk density through the development of a porous soil structure.

Used the pedotransfer models of artificial neural network program Rosetta in this case, produces promising results only for sand, silt, and clay percentages and bulk density as data input. This might be due to the fact that the van Genuchten's parameters. which express the shape of the water retention curve, are sensitively affected by the wide ranges of soil properties as in this alluvial soil. Even though the data used in this study was obtained from a relatively small area, large spatial and temporal variability in physical and hydraulic properties of this alluvial soil may cause such a low performance in predictions. Similar results were observed by Minasny et al. (1999), Nemes et al. (2002) and Merdun et al. (2006).

\section{Conclusions}

In conclusion the course of the water retention curves obtained on the basis of nonlinear regression analysis $\left(\mathrm{R}^{2}\right)$ for each layers of soil profiles indicates a good adjustment of the approximating functions used to the retention capacity obtained from the measurements. The pedotransfer models of artificial neural network program RETC and Rosetta in this case produces promising results and its advantages can be utilized by developing of water hydraulic characteristics of alluvial soils in future studies. The simulation of the RETC using the van Genuchten equation with a percentages of sand, silt and clay and also bulk density entry value was adequate to estimate soil water contents for four soil profiles located in the Odra River valley, in spite of the differences obtained between observed and predicted data.

On the basis of the conducted research it can be concluded that share of easily accessible water for plants was higher of the hardly accessible water for plants. It is very important from the viewpoint of the production and cultivation. Alluvial soil can hold moisture and is very fertile so in dry years plants do not suffer from a shortage of water.

Studies on water retention of alluvial soils should be extended in order to obtain more data that will be used for proper statistical inference. Other properties of alluvial soils, e.g. water permeability, should also be carried out.

\section{REFERENCES}

[1] Bednarek, R., Prusinkiewicz, Z. (1999): Soil Geography. - PWN, Warszawa. (In Polish).

[2] Bogdał, A., Borek, Ł., Ostrowski, K. (2014): Influence of subsoiling on changes of physical and water properties of soil Lessivés. - Acta Scientiarum Polonorum Formatio Circumiectus 13(4): 35-43. (In Polish). 
[3] Bullinger-Weber, G., Le Bayon, R., Guenat, C., Gobat, J. M. (2007): Influence of some physicochemical and biological parameters on soil structure formation in alluvial soils. European Journal of Soil Biology 43(1): 57-70.

[4] Cameira, M. R., Fernando, R. M., Pereira, L. S. (2003): Soil macropore dynamics affected by tillage and irrigation for a silty loam alluvial soil in southern Portugal. - Soil and Tillage Research 70(2): 131-140.

[5] Dobrovol'ski, G. V., Balabko, P. N., Stasjuk, N. V., Bykova, E. P. (2011): Alluvial soils of river floodplains and deltas and their zonal differences. - Arid Ecosystems 1(3): 119124.

[6] Dwevedi, A., Kumar, P., Kumar, P., Kumar, Y., Sharma, Y. S., Kayastha, A. M. (2017): Soil Sensors: Detailed Insight into Research Updates, Significance and Future Prospects. - In: Grumezescu, A. M. (ed.) New Pesticides and Soil Sensors. Academic Press, London, pp. 561-594.

[7] Fashi, F. H., Gorji, M., Shorafa, M. (2016): Estimation of soil hydraulic parameters for different land-use. - Modeling Earth Systems and Environment 2: 0-170.

[8] Gama-Castro, J. E., Solleiro-Rebolledo. E., Vallejo-Gómez, E. (2000): Weathered pumice influence on selected alluvial soil properties in west Nayarit. Mexico. - Soil and Tillage Research 55(3-4): 143-165.

[9] Hakl, J., Šantrůč, Ek, J., Kocourková, D., Fuksa, P. (2007): The effect of the soil compaction on the contents of alfalfa root reserve nutrients in relation to the stand density and the amount of root biomass. - Soil \& Water 2(2): 54-58.

[10] Hao, X., Ball, B. C., Culley, J. L. B., Carter, M. R., Parkin, G. W. (2008): Soil Density and Porosity. - In: Carter, M. R., Gregorich, E. G. (eds.) Soil Sampling and Methods of Analysis. 2nd ed. CRC Press and Canadian Society of Soil Science, Boca Raton, FL., pp. 743-759.

[11] Hillel, D. (1998): Environmental Soil Physics. - Academic Press, New York.

[12] Hollenbeck, K. J., Šimůnek, J., Van Genuchten, M. Th. (2000): RETMCL: Incorporating maximum-likelihood estimation principles in the RETC soil hydraulic parameter estimation code. - Computers \& Geosciences 26: 319-327.

[13] Hong, S. Y., Minasny, B., Han, K. H., Kim, Y., Lee, K. (2013): Predicting and mapping soil available water capacity in Korea. - Peer J. 1: e71.

[14] Huong, P. T. T., Everaarts, A. P., Neeteson, J. J., Struik, P. C. (2013): Vegetable production in the Red River Delta of Vietnam. I. Opportunities and constraints. - NJAS Wageningen Journal of Life Sciences 67: 27-36.

[15] Iqbal, J., Thomasson, J. A., Jenkins, J. N., Owens, P. R., Whisler, F. D. (2005): Spatial variability analysis of soil physical properties of alluvial soils. - Soil Science Society of America Journal Abstract - Soil \& Water Management \& Conservation 69(4): 1338-1350.

[16] IUSS Working Group WRB (2006): World Reference Base for Soil Resources 2006. World Soil Resources Reports No. 103. FAO, Rome.

[17] Kahlon, M. S., Khurana, K. (2017): Effect of land management practices on physical properties of soil and water productivity in wheatmaize system of northwest India. Applied Ecology and Environmental Research 15(4): 1-13.

[18] Kondracki, J. (2011): Regional Geography of Poland. - PWN, Warszawa. (In Polish).

[19] Kundzewicz, W. Z., Førland, E. J., Piniewski, M. (2017): Challenges for developing national climate services - Poland and Norway. - Climate Services 8: 17-25.

[20] Liu, H., Li, B., Ren, T. (2015): Soil profile characteristics of high-productivity alluvial cambisols in the North China Plain. - Journal of Integrative Agriculture 14(4): 765-773.

[21] Luptáčik, P., Miklisová, D., Kováč, L. (2012): Diversity and community structure of soil Oribatida (Acari) in an arable field with alluvial soils. - European Journal of Soil Biology 50: 97-105.

[22] Mebius, L. J. (1960): A rapid method for the determination of organic carbon in the soil. - Analytica Chimica Acta 22: 120-124. 
[23] Merdun, H., Çınar, Ö., Meral, R., Apan, M. (2006): Comparison of artificial neural network and regression pedotransfer functions for prediction of soil water retention and saturated hydraulic conductivity. - Soil and Tillage Research 90(1-2): 108-116.

[24] Minasny, B., McBratney, A. B., Bristow, K. L. (1999): Comparison of different approaches to the development of pedotransfer functions for water-retention curves. Geoderma 93: 225-253.

[25] Minasny, B., Hopmans, J. W., Harter, T., Eching, S. O., Tuli, A., Denton, M. A. (2004): Neural networks prediction of soil hydraulic functions for alluvial soils using multistep outflow data. - Soil Science Society of America Journal 68(2): 417-429.

[26] Mocek, A., Drzymała, S. (2010): Geneza analiza i klasyfikacja gleb. - Wyd. UP, Poznań. (In Polish).

[27] Nasta, P., Assouline, S., Gates, J. B., Hopmans, J. W., Romano, N. (2013): Prediction of unsaturated relative hydraulic conductivity from Kosugi's water retention function. Procedia Environmental Sciences 19: 609-617.

[28] Nawaz, M. F., Bourrié, G., Trolard, F. (2013): Soil compaction impact and modelling. A review. - Agronomy for Sustainable Development 33(2): 291-309.

[29] Nemes, A., Schaap, M., Wösten, H. (2002): Validation of international scale soil hydraulic pedotransfer functions for national scale applications. - Symposium no. 04 on 17th WCSS. Paper no. 934, poster presentation 14-21. August, Thailand (2002).

[30] Nguyen, P. M., Haghverdi, A., De Pue. J., Botula, Y-D., Le, K. V., Waegeman, W., Cornelis, W. M. (2017): Comparison of statistical regression and data-mining techniques in estimating soil water retention of tropical delta soils. - Biosystems Engineering 153: 12-27.

[31] Pagliai, M., Vignozzi, N., Pellegrini, S. (2004): Soil structure and the effect of management practices. - Soil \& Tillage Research 79: 131-143.

[32] Paluszek, J. (2011): Kryteria oceny jakości fizycznej gleb uprawnych Polski. - Acta Agrophysica. Rozprawy i Monografie 191: 0-139. (In Polish).

[33] Pandey, N. G., Charkavorty, B., Kumar, S., Mani, P. (2006): Comparison of estimated saturated hydraulic conductivity for alluvial soils. - Hydrology Journal 28(3-4): 59-72.

[34] Phogat, V. K., Tomar, V. S., Dahyia, R. (2015): Soil Physical Properties (Chapter 6). In: Rattan, R. K., Katyal, J. C., Dwivedi, B. S., Sarkar, A. K., Bhattachatyya Tapan, Tarafdar, J. C., Kukal, S. S. (eds.) Soil Science: An Introduction. First Edition. Indian Society of Soil Science, New Delhi, pp.135-171.

[35] Pirastru, M., Niedda, M. (2013): Evaluation of the soil water balance in an alluvial flood plain with a shallow groundwater table. - Hydrological Sciences Journal 58(4): 898-911.

[36] PTG (2011): Polish soil classification. Fifth edition. - Soil Science Annual 62(3): 0-193. (in Polish).

[37] Qanza, H., Maslouhi, A., Abboudi, S. (2015): Experience of inverse modelling for estimating hydraulic parameters of unsaturated soils. - Russian Meteorology and Hydrology 41(11-12): 779-788.

[38] Rawls, W. J., Pachepsky, Y. A., Ritchie, J. C., Sobecki, T. M., Bloodworth, H. (2003): Effect of soil organic carbon on soil water retention. - Geoderma 116(1-2): 61-76.

[39] Reynolds, W. D., Bowman, B. T., Drury, C. F., Tan, C. S., Lu, X. (2002): Indicators of good soil physical quality: density and storage parameters. - Geoderma 110: 131-146.

[40] Rubio, C. M., Poyatos, R. (2012): Applicability of Hydrus-1D in a Mediterranean mountain area submitted to land use changes. - International Scholarly Research Notices 2012: Article ID 375842.

[41] Rumsey, D. J. (2016): Statistics for Dummies. 2nd edition. - Wiley, New York.

[42] Schaap, M. G., Leij, F. J., Van Genuchten, M. T. (1998): Neural network analysis for hierarchical prediction of soil water retention and saturated hydraulic conductivity. - Soil Science Society of America Journal 62(4): 847-855. 
[43] Schaap, M. G., Leij, F. J., Van Genuchten, M. T. (2001): ROSETTA: a computer program for estimating soil hydraulic parameters with hierarchical pedotransfer functions. - Journal of Hydrology 251: 163-176.

[44] Schofield, R. K. (1935): The $\mathrm{pF}$ of the water in soil. - Transactions of the $3^{\text {rd }}$ International Congress of Soil Science 2: 37-48.

[45] Schoonover, J. E., Crim, J. F. (2015): An introduction to soil concepts and the role of soils in watershed management. - Journal of Contemporary Water Research \& Education 154(1): 21-47.

[46] Shwethaa, P., Varijab, K. (2015): Soil water retention curve from saturated hydraulic conductivity for sandy loam and loamy sand textured soils. - Aquatic Procedia 4: 11421149.

[47] Šimůnek, J., Van Genuchten, M. Th., Šejna, M. (2005): The HYDRUS-1D Software Package for Simulating the One-Dimensional Movement of Water, Heat and Multiple Solutes in Variably-Saturated Media. - Dep. of Environ. Sci. Univ. of California, Riverside.

[48] Soil Survey Staff (1999): Soil Taxonomy: A Basic System of Soil Classification for Making and Interpreting Soil Surveys. 2nd edition. - Natural Resources Conservation Service. U.S. Department of Agriculture Handbook, Washington.

[49] Szafer, W. (1966): The vegetation of Poland. - International Series of Monographs in Pure and Applied Biology/Botany Division/ vol. 9. Pergamon Press, Oxford.

[50] Van Genuchten, M. T. (1980): A closed-form equation for predicting the hydraulic conductivity of unsaturated soils. - Soil Science Society of America Journal 44: 892-898.

[51] Van Genuchten, M. T., Leij, F. J., Yates, S. R. (1991): The RETC Code for Quantifying the Hydraulic Functions of Unsaturated Soils. Version 1.0. - EPA Report 600/2-91/065. U.S. Salinity Laboratory. USDA-ARS, Riverside, California.

[52] Wassar, F., Gandolfi, C., Rienzner, M., Chiaradia, E. A., Bernardoni, E. (2016): Predicted and measured soil retention curve parameters in Lombardy region north of Italy. International Soil and Water Conservation Research 4(3): 207-214.

[53] Yassoglou, N., Tsadilas, C., Kosmas, C. (2017): Specific Characteristics of Alluvial Soils. - In: Yassoglou, N., Tsadilas, C., Kosmas, C. (eds.) The Soils of Greece. World Soils Book Series. Springer, Cham. 